\title{
The Death of Septimus and Virginia Woolf's Attitude Towards Rationality
}

\author{
Hengliang Zhang ${ }^{1, *}$
}

\author{
${ }^{1}$ School of Foreign Languages and Cultures, Sichuan University, Chengdu, Sichuan 610065, China \\ *Corresponding author. Email: louisnanyang@163.com
}

\begin{abstract}
This paper attempts to deeply explore the death of Septimus from the perspective of the opposition between humanitarianism and rationalism. Different from previous critics who attributed Septimus's death to shell shock, this paper attempts to argue that Septimus, the symbol of humanitarianism, is forced to commit suicide by Bradshaw, the symbol of rationalism, because the former's lament for the loss of humanitarianism is interpreted by the latter as symptoms of madness, the whole process of which reveals the transgression of rationalism on humanitarian spirit. By indicating the spiritual identification between Septimus and Clarissa, and employing Clarissa as the incantation of her spirit, Virginia Woolf subtly denotes the spiritual identification between Septimus and herself. Virginia Woolf metaphorically employs the death of Septimus to embody the transgression of rationalism on humanitarianism in her time so as to make a social warning.
\end{abstract}

Keywords: humanitarianism, rationality, Mrs. Dalloway

\section{INTRODUCTION}

The death of Septimus Warren Smith is a dramatic incident in Virginia Woolf's Mrs. Dalloway, which has not been sufficiently studied. Most of the critics in China deem Septimus as the victim of shell shock, and thereby regard his death as the revelation of Virginia Woolf's anti-war sense. Such an interpretation seems impeccable at the first sight, for the novella is set in 1923, shortly after the war, and shot through with the indication of war trauma, as is evidenced by the loss of relatives in many families at the beginning of the novella. However, Virginia Woolf clearly points out in her diary "In this book I have almost too many ideas. I want to give life and death, sanity and insanity; I want to criticize the social system, and to show it at work, at its most intense." [1] In this sense, the character setting of Septimus clearly fleshes out the aforementioned ideas. His war experience and committing suicide serve as the marker of life and death. $\mathrm{He}$ is diagnosed with madness yet sporadically shows the presence of mind, which embodies the entanglement of sanity and insanity. His judgment "it must be the fault of the world" ${ }^{1}$ [2]

Virginia Woolf, Collected Novellas of Virginia Woolf, p.102 (Stella McNichol ed., 1992). All the other textual quotations coming from the same book will be noted with the page number in the paper. As for this point, it will not be noted otherwise. obliquely voices Woolf's social criticism. In view of the complexity in the image projection of Septimus, it would be too rash to simply confine Septimus's death within the domain of anti-war sense.

The interpretation of international critics Rilely H. Floyd and Evelyn T. Chan may shed light on our understanding Septimus and his death in a new way. Rilely approaches the novella from ethics and argues that the irreconcilable confrontation between civilian ethics and war ethics leads to Septimus's schizophrenia and his final death. ${ }^{2}$ Evelyn focuses on the power and discourse in the novella and contends that the suppression of medical discourse drives Septimus to commit suicide. ${ }^{3}$ These two papers feature innovation yet lack a comprehensive perspective, for they each pays attention to just one party of the incident, either the doctor or the patient. In the book, Septimus jumped out of the window because he knew Dr. Holmes was climbing stairs to see him, an action deemed by him as a threat. Seemingly the death of Septimus reflects the confrontation between the doctor and the patient, who are in a constrained relationship in the book.

Rilely H. Floyd, "I Must Tell the Whole World' Septimus Smith as Virginia Woolf's Legal Messenger", Indiana Law Journal, vol.91, 2016, p.1473-1496.

Evelyn T. Chan, "The Ethics and Aesthetics of Healing: Woolf, Medicine and Professionalization", Women's Studies, vol.43, 2014, p.25-51 
However, a critical reading will uncover the disguised conflict, humanitarianism versus rationalism, respectively represented by Septimus and doctors in the novella (Dr. Holmes \& Sir William Bradshaw). Inspired by yet different from Evelyn's research, this paper tends to argue that Virginia Woolf metaphorically employs the death of Septimus to embody the transgression of rationalism on humanitarianism in her time so as to make a social warning.

The novella was set in 1923, when the development of modernism reached the apex. "The modern spirit is derived from the Renaissance and the Enlightenment," [3] which respectively give rise to humanitarianism and rationalism, two powerful and parallel pillars of modernism. However, in the course of time, "rationalism, one of the two pillars of modernism, won a predominant victory. Consequently, the subjectivity of human beings waned, rational beings parted with subjectivity, and finally modernity lost its meaning." [4] Since the hallmark of humanitarianism is the emphasis on subjectivity, the wane of the latter denotes the fall of the former. Therefore, the trauma Septimus undergoes is not caused by shells but by his squashed ideal (humanitarianism) in the modern war, which features the presence of rationalism. In contrast with Septimus, Dr. Holmes and Sir William Bradshaw in particular, represent rationalism. Their suppression and manipulation of Septimus embody not only the discipline of medical discourse towards individual, but also the encroachment of rationalism on humanitarianism.

The two concepts of science and rationality need to be distinguished. The former, a visible sign in the text, takes the form of automobiles and aeroplanes, whereas the latter falls into the territory of invisible. Yet, ever since the Enlightenment, the advocacy of rationality leads to the fall of theology and the rise of science. "If there is no rationality, there will be no science. Rationality constitutes the soul of science." In the late 19th century, when Nietzsche declared the death of God, science was gathering momentum to replace religion, as is testified by people's increasing passion for science. This explains why when Septimus caught the illusion of a dog turning into a man, his first reaction was to seek a "scientific explanation" (83). Besides, when he found voice could under certain circumstance quicken the growth of trees in the park, he contended that "one must be scientific, [and] above all scientific."(49) Given that science constitutes the ultimate parameter of value, it is consecrated and thereby becomes a new religion. Therefore, science, in conjunction with rationality, falls into the opposite camp of humanitarianism. As for this point, Vicki Tromanhauser expressed the same idea by stating that "Woolf suggests the culture's demise through the very social strategies and sciences - medical, ecumenical and evolutionary." [5]

\section{THE SPIRITUAL DILEMMA OF SEPTIMUS, THE SYMBOL OF HUMANITARIANISM}

Septimus features the love of reading in the book, as is epitomized by his "devouring Shakespeare, Darwin, The History of Civilization, and Bernard Shaw."(95) To add up his booklist, Virginia Woolf purposefully highlights Septimus's "ability to read, Dante for example, quite easily."(97) Shakespeare and Dante are masters in the Renaissance, the works of whom is acknowledgedly filled with strong humanitarian color. In addition, the play of Bernard Shaw bears the hallmark of humanitarian thought. Septimus's ravenous reading of aforementioned books provides clues for the interpretation of his mental state. Moreover, Woolf further stresses "he went to France to save an England which consisted almost entirely of Shakespeare's plays." In this sense, it is easy to see that Septimus is projected as a defender of humanitarianism in the text.

However, the humanitarianism espoused by Septimus is shattered to pieces in the modern war (WWI), in which rationality plays a pivotal role. First, the advocacy of rationality provides the theoretical foundation for the outbreak of WWI. Social Darwinism, drawn from Darwin's evolution theory, features the justification of class suppression and finally constitutes the rationale of the struggle for hegemony between nations. Second, the employment of weapons of mass destruction, like machine-guns, tanks and gas, which are the products of scientific progress, greatly changes the scope and mode of wars. Instead of directly presenting the cruelty of wars, Woolf chose an oblique way, as is exemplified by a third-person comment, "it was a miracle thinking of the war, and thousands of poor chaps, with all their lives before them, shoveled together, already half forgotten."(118) The word "poor chaps" vividly conveys the sense of desperation when helpless individuals facing the meat-grinding war. Septimus, the true believer of humanitarianism, in face of such a cruel war, suffered a great shock.

Septimus deemed it his biggest crime that "he could not feel" (96) when his friend, "Evans was killed, just before the Armistice, in Italy."(96) Here, the term "could not feel" refers to Septimus's showing no grief in face of his friend's death, an epitome of rationality. In the battlefield, the immersion into personal feelings may easily leads to danger. To survive, rationality must prevail over feelings, that's what "the war had taught him."(96) However, in the eyes of Septimus, when a person is deprived of the ability to feel, he is disqualified to 
be a human being. To make things worse, the death of Evans happened in Italy, the origin of the Renaissance. In such a place, Septimus violated the humanitarian principle, which constituted an irony in the first level. Besides, Septimus, a soldier of Britain, joined the war to defend what Shakespeare meant to him, the humanitarian spirit. Quite ironical was that he won the war but lost what he wanted to defend.

Therefore, it is easy to see Septimus's trauma lies not in shell shock, but in the collapse of his spiritual pillar, the fall of humanitarianism. He committed that crime and "the verdict of human nature on such a wretch was death."(100) Actually, "his crime should be interpreted as a moral one rather than a legal one." [6] In the text, Septimus was frequently visited by the ghost of Evans, which was regarded by him as humiliating reminder of his breach of human nature. Septimus trudged with moral weight and to him, "the world itself was without meaning."(98) In such a world, "they hunt in packs. Their packs scour the desert and vanish screaming into the wilderness."(99) Here, "desert" and "wilderness" may easily remind readers of Eliot's The Waste Land, in which the absurdity and meaninglessness of existence are exposed to the utmost degree. Virginia Woolf employs the experience of Septimus, a single case, as a metaphor to reflect the mental state of the British society in her time so as to criticize the overadvocacy of rationality and to reemphasize human nature. As is pointed out by Lisa Colletta, "Virginia Woolf thought that her reputation might well rest on her satiric sensibilities... and in most of her writing her satiric impulses are evident." [7]

\section{THE STRANGLEHOLD OF RATIONALITY ON HUMAN NATURE REFLECTED IN THE DOCTOR-PATIENT RELATIONSHIP}

In the novella, both Holmes and Sir William Bradshaw are doctors, and to be specific, Bradshaw is a psychiatrist. At the beginning of the 20th century, the rise of Freud's psychological analysis marked people's ambition to conquer the unknown territory with rationality/science. In this sense, the identity of being a psychiatrist is itself an indication of the advocacy of rationality.

The process of Septimus's visiting Dr. Holmes and Bradshaw and receiving their treatment, reflects the unequal position between humanitarian spirit and rationality. In a doctor-patient relationship, the patient tends to take up the weak position. The patient's receiving cure embodies humanitarian spirit falls under the rule of rationality. In the book, Woolf deliberately employs the contrast in physical feature between Septimus and Dr. Holmes to imply the fall of humanitarian spirit and the rise of rationality. Different from Septimus, who was weak and bony, Dr. Holmes was "large, fresh-colored and handsome." (100) Besides outlook, Woolf also uses the contrast in characters' inner-worlds to strengthen the confrontation between humanitarianism and rationalism, which gets crystalized in the opposed attitudes towards reading between Septimus and Bradshaw. In the eyes of Bradshaw, "the fellow Septimus made a distasteful impression." (104) "There was in Sir William, who had never had time for reading, a grudge, deeply buried, against cultivated people who came into his room and intimated that doctors... are not educated men." (104-105) Here Bradshaw highlights that what distinguishes Septimus and him is whether they read books. Given that Bradshaw is a psychiatrist, a profession which requires a lot of reading, books here refer not to ones in common sense but to ones featuring humanitarian spirit. Thus the opposition between Septimus and Bradshaw actually uncovers the confrontation between human nature and rationality. As a consequence, Bradshaw spared no effort to tag Septimus with madness. "He could see the first moment they came into the room...it was a case of complete breakdown for Septimus." (104) "Sir William said he never spoke of "madness'; he called it not having a sense of proportion."(Ibid.) However, the question is whether Septimus really goes mad. In the novella, the reason for Septimus's being charged with madness lies in his having illusions (Evans's ghost). As is analyzed above, Evans' ghost is the embodiment of Septimus's pricked conscience. More important, before he died, Septimus could discern the real from the illusive, and the live from the dead, as is evidenced by his asking "as for the visions, the faces, the voices of the dead [Evans], where are they?" (140) In view of this, placing the tag of madness upon Septimus is groundless, which reflects Bradshaw's stigmatization of Septimus.

Actually Bradshaw aims at not only Septimus's stigmatization but also his segregation. Facing Septimus's symptom, Bradshaw offered the plan of cure as "going into a home... where we will teach you to rest." (104) Here "home" refers to one asylum in the countryside where mental patients are compulsively segregated, disciplined, and watched in the name of treatment. To justify such a cruel plan, Bradshaw explained that "worshiping proportion, Sir William not only prospered himself but made England prosper, secluded her lunatics, forbade childbirth, penalized despair, made it impossible for the unfit to propagate their views." (106) In the views of Michael Foucault, rationality lays emphasis on order and norm, which consolidates the rule of society whereas madness, as the opposite of rationality, may easily leads to social unrest. Therefore the best means of punishing madness is locking it within the 
Panopticon, where it will always receive the discipline and gaze of rationality. As is stated by Foucault, "here reason reigned in the pure state, in a triumph arranged for it in advance over a frenzied unreason. Madness was thus torn from that imaginary freedom... it had been sequestered, and in the fortress of confinement, bound to Reason, to the rules of morality and to their monotonous nights." [8] In the case of Septimus's treatment, it is easy to see that rationality aligns with power to suppress human nature.

In face of such a threat, Septimus regards Dr. Holmes and Bradshaw as monsters. In his eyes, "He [Septimus] was in their power! Holmes and Bradshaw were on him! The brute with the red nostrils was snuffing into every secret place!" (141) Holmes's unexpected visit constitutes the last straw that breaks a camel's back. Confronted with their suppression step by step, Septimus has no choice but to commit suicide. What is dramatic is that when the ambulance called to save Septimus ran past Peter, Peter made a comment "it was one of the triumphs of civilization."(144) Peter's original intention was to praise "the efficiency, the organization, and the communal spirit of London" (Ibid.), yet Woolf intentionally juxtaposes the death of Septimus and the comment of Peter, which opens new way of interpreting Peter's comment, that is, the death of Septimus is one of the triumphs of civilization. Here civilization means rationality, for in the first place, the ambulance owes its existence to the development of science/rationality, and secondly, the ambulance belongs to the medical sphere, where science/rationality is highlighted. In view of this, it is clear to see that Woolf obliquely employs Peter's comment to point out the real reason of Septimus's death, the stranglehold of human nature by over-advocacy of rationality.

\section{VIRGINIA WOOLF'S ATTITUDE TOWARDS RATIONALITY}

The relationship between Clarissa and Septimus is quite thought-provoking. From beginning to end, the two have no direct contact in the novella. However, due to Woolf's ingenious design, critical readers can read between the lines and find the spiritual conformity between the two. For example, the idea of committing suicide is what they have in common. Septimus once said "I [would] kill myself." (44) As for Clarissa, from time to time she was also assailed by the idea of death. "Did it matter that she must inevitably cease completely [?] All this must go on without her; did she resent it [?]" (39) Besides, Septimus, bothered by his pricked conscience, felt "he was falling." (98) Similarly, Clarissa once made a comment, "What a plunge!" (35) The "plunge" here not only tallies with the image of a falling Septimus, but also conformed to the means of Septimus's committing suicide, jumping from the window. In addition, Septimus deemed "the world itself [was] without meaning" (98) and likewise Clarissa thought she was "obscured in her own life, let drop every day in corruption, lies, [and] chatter." (169)

However, to realize the spiritual connection between Septimus and Clarissa is only a halffinished project. It is acknowledged that during the composition of this book, Woolf serves as the prototype of Clarissa. Vereen M. Bell and Vereen Bell even assert that "own Clarissa Dalloway and you own Virginia Woolf." [9] By projecting Clarissa as a woman with knowledge and homosexual tendency, which is the same with Woolf herself, and denoting the spiritual connection between Clarissa and Septimus, as is mentioned above, Woolf aims at the identification with Septimus, or as Michael North puts it, "the occult sympathy of Smith and Dalloway." [10] Further, Clarissa's interpretation of Septimus's death reveals the import of his image-projection, to criticize the over-advocacy in Woolf's time.

Clarissa's homosexual tendency is indirectly mentioned in the book. At an early age, Clarissa was kissed by Sally, her girl-friend, which left her a deep impression. In spite of this kiss, they respectively entered into wedlock with a male spouse. In the text, Clarissa "lived alone in a small room with a narrow bed." (55) The small room and narrow bed conveys a strong sense of suppression. "Narrower and narrower would her bed be. The candle was half burnt down and she had read deep in Baron Marbot's Memoirs." (Ibid.) Next, when Clarissa recalled her association with Sally, flowers take up the center stage. "Sally went out, picked hollyhocks, dahlias-all sorts of flowers that had never been seen together." (57) Due to the similarity in outlook, candles are often used to denote the penis in western literature, and thus the half-burnt candle may be understood as the implication of the spoiled sexual life. In contrast, flowers tend to be employed as the metaphor of the vagina, and the juxtaposition of flowers, like the friction of female sexual organs, may refer to female homosexual activities. Woolf uses the image of candles and flowers to imply Clarissa's homosexual desire, which has been suppressed, as is testified by the image of the narrow bed. Actually, in ancient Greek and Roman times, both homosexuality and heterosexuality are quite common. "Homosexuality was accepted in ancient Greek society, be it in religion or in law. It was performed in rituals and praised in literature." [11] Ever since then, although the suppression of homosexuality sporadically existed, it was not until the rise of rationality, which required order and norm, that the suppression of homosexuality became systemized. "Foucault revealed that homosexuality always existed in the history and 
that such a fact was the product of ideology... In the past, homosexuality was tagged on a single person, regarded as a secluded action. In contrast, ever since 1870, homosexuality has been used to define a group of people and a packet of actions." [12] Therefore, in the novella, Clarissa chose to marry Dalloway, to a greater degree, because she wanted to "use heterosexual marriage to cover her homosexuality." [13] As is stressed by Pam Morris, "there are forces represented in the text that are hostile to disorder and heterogeneity, forces that are intent upon imposing systems of discipline and conformity on any unregulated form of existence." [14] In view of this, sex, which is an otherwise natural human right, is reluctantly combined with power and brought under gaze. In this sense, the suppression of sex is the suppression of human nature, which Woolf is committed to opposing in this book. It is also at this point that the spiritual connection between Septimus and Clarissa, further, Septimus and Woolf, is brought into relief.

\section{CONCLUSION}

Woolf's criticism of rationality in the book is not a total one but rather a counteraction against the over-advocacy of rationality. The author employs the death of Septimus to reveal the severity of the suppression of humanitarianism by rationality. Actually, the origin of Woolf's criticism should be interpreted in the course of history. In the first half of 19th century, when Auguste Comte put forward positivism, the advocacy of rationality reached the apex. In contrast, the study of humanitarianism, due to its strong metaphysical, subjective and unverifiable feature, was bombarded with rejection and detestation, which later gave rise to the theme of alienation in modernism. Woolf's criticism of rationality is the further development of the alienation theme and also a useful reflection on modernity "during the peak of literary modernism." [15]

One thing needs to be stressed, that is, this paper approaches the death of Septimus from the confrontation between humanitarianism and rationalism, a perspective seldom touched before and thus may challenge some readers' preexisting comprehension of the novella. To justify such a challenge, the writer of this paper would like to quote from Jonathan Culler, "meaning is contextbound, but context is boundless." [16] In this sense, this paper signals an attempt to re-contextualize the death of Septimus in the hope of a novel interpretation. In this way literature with incessantly opened ways of approach and appreciation, will thrive in the course of time and always provide readers with solace and significance.

\section{References}

[1] Virginia Woolf, A Writer's Diary: Being Extracts From the Diary of Virginia Woolf , Leonard Woolf ed., 1953, p.57.

[2] Virginia Woolf, Collected Novellas of Virginia Woolf, Stella McNichol ed., London: Macmillan, 1992, p.102

[3] Zhang Qingxiong, "Postmodernism and Ideological Emancipation", in Fudan Journal (Social Science Edition), No.5, 2009, p.22.

[4] Wang Zhijie, "Rationality: Between Science and Religion", in Guizhou Social Sciences, No.6, 2005, p.75.

[5] Vicki Tromanhauser, "Mrs. Dalloway's 'Animals and the Humanist Laboratories", in Twentieth Century Literature, Vol.58, 2012, p.188.

[6] Rilely H. Floyd, "'I Must Tell The Whole World': Septimus Smith as Virginia Woolf's Legal Messenger", in Indiana Law Journal, vol.91, 2016, p.1474.

[7] Lisa Colletta, Dark Humor and Social Satire in the Modern British Novel, New York: Palgrave Macmillan, 2003, p.37.

[8] Michael Foucault, Madness and Civilization: A History of Insanity in the Age of Reason, Vintage, 1988, p.64.

[9] Vereen M. Bell \& Vereen Bell, "Misreading Mrs. Dalloway", in The Sewanee Review, winter, 2006, p.94

[10] Michael North, Reading 1922: A Return to the Scene of the Modern, Oxford UP, 1999, p.84

[11] Zhu Gang, Western Literary Theories in the Twentieth Century, Nanjing: Nanjing UP, 2006, p.519.

[12] Ibid

[13] Pan Jian, "The Rebellion against the Compulsive Heterosexual Culture: Woolf's Homosexual Narrative", in Foreign Literature Studies, No.2, 2011, p.63.

[14] Pam Morris, Jane Austen, Virginia Woolf, and World Realism, Edinburgh: Edinburgh UP, 2017, p.64.

[15] Emily Griesinger, "Religious Belief in a Secular Age: Literary Modernism and Virginia Woolf's Mrs. Dalloway", in Christianity and Literature, Vol.64, 2015, p.439.

[16] Jonathan Culler, Literary Theory: A Very Short Introduction, New York: Sterling Publishing Corporation, 2007, p.92 